\title{
Project Management Competences As a Driver Of Growing Economies
}

\author{
Vladimir Obradović \\ Faculty of organisational sciences \\ University of Belgrade \\ vladimir.obradovic@fon.bg.ac.rs
}

\begin{abstract}
Economic growth cannot be achieved without adequate strategy implemented through projects. Consequently, growth depends on the success of selected and executed projects. On the other hand, project managers, project team members, and other key personnel involved in project substantially influence overall results of the projects. This paper examines the state of the practice in this area. A survey conducted has the primary purpose to investigate the level of project management competences in Serbia and draw some conclusions that would serve as a base for future actions. Findings and recommendations of the paper could be used as an input for policymakers to develop a plan for future
\end{abstract}

\section{Keywords-project, competence, economy, growth}

\section{INTRODUCTION}

In the process of economic development, growing societies face numerous challenges. Limited resources are certainly one of the most critical obstacles that stand in the way of the more rapid growth. When thinking about resources, one usually thinks of natural resources, energy etc. However, the most limiting resource can be missing quantity of adequate competences, meaning that growing economies need a substantial level of people with sufficient knowledge, skills and experience to foster development properly.

The key driver of every economy regardless of its level of development is undoubtedly the public sector as a single largest investor [1]. Since the investments, as a rule, are organised in various programmes, portfolios, and projects, the importance of project managers is more than evident $[2,3,4]$

Even though various measures are necessary to improve project management practice [5] competences of project managers in the public sector are crucial to the effectiveness of public sector organisations [6,7] that tend to be significant investors and drivers of economic growth.

The need for cultivating active project managers is critical because a project's success or failure can be vital to organisational interests and the influence of the project manager is crucial to the success of the project $[4,8,9,10,11]$. Specific attitudes, behaviours and competencies are characteristic of results-oriented, effective project managers [12].
Managerial effectiveness refers to a manager's demonstrated proficiency in a repertoire of knowledge, skills, and abilities (i.e. competences) that promote organisational success [13]. Changes are more successfully implemented via projects that require new skills $[14,15]$.

Table 1 presents ten competencies, with associated behaviours, indicative of an effective results-oriented project manager [12].

TABle 1. Competences of EFFeCtive Project Managers [12]

\begin{tabular}{|l|l|}
\hline Cluster & Competency \\
\hline $\begin{array}{l}\text { Goal and Action } \\
\text { Management }\end{array}$ & $\begin{array}{l}\text { Diagnostic Use of Concepts } \\
\text { Efficiency Orientation } \\
\text { Proactive }\end{array}$ \\
\hline Leadership & $\begin{array}{l}\text { Leadership } \\
\text { Self-Confidence } \\
\text { Use of Oral Presentations }\end{array}$ \\
\hline $\begin{array}{l}\text { Human Resource } \\
\text { Management }\end{array}$ & $\begin{array}{l}\text { Managing Group Processes } \\
\text { Use of Socialised Power }\end{array}$ \\
\hline $\begin{array}{l}\text { Directing } \\
\text { Subordinates }\end{array}$ & $\begin{array}{l}\text { Developing Others } \\
\text { Use of Unilateral Power }\end{array}$ \\
\hline Focus on Others & Stamina and Adaptability \\
\hline
\end{tabular}

The women project managers were found to exhibit qualities of transformational, democratic and peopleoriented leadership styles. They did not believe that gender should be a determinant of their leadership style, but that working as a project manager required individual leadership skills and competencies to meet the project's objectives irrespective of gender [16]. But a skilled project manager consistently applies universal processes and skills to bring consistency and results to one project after another [17].

The model of "command and control" project management, even though commonly used, does not work in today's environment, but rather that style of management tends to have the opposite of the intended effect on projects and team members $[18,19]$.

Following work previously cited in this article, one may conclude that there is a unified opinion that a set of specific competences of project managers is needed to create adequate prerequisites for project success. The difference comes in the definition of the competences required. Hence, a survey was conducted in Serbia to establish a set of competences needed at 
this moment to foster rapid socio-economical development.

\section{COMPETENCES IDENTIFIED}

A survey was conducted in Serbian public sector to determine a broad set of elements that influence or could influence project management in Serbia. Since the government is the single largest investor in the country and the primary influencer of economic growth, the survey was conducted among civil servants dealing with projects in different ways.

The poll scoped 110 respondents, 84 or $76 \%$ were women, and 26 or $24 \%$ were men. The sample was well distributed in terms of age and experience, as given in Figure 1 and Figure 2.

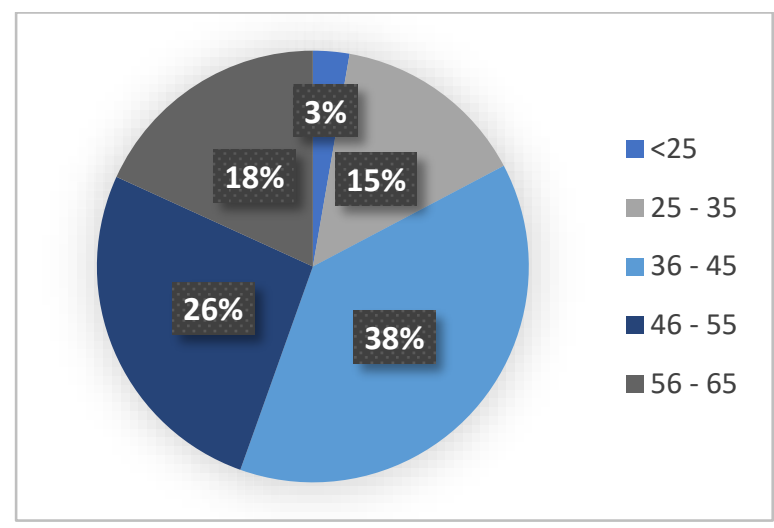

Fig. 1. Age of respondents

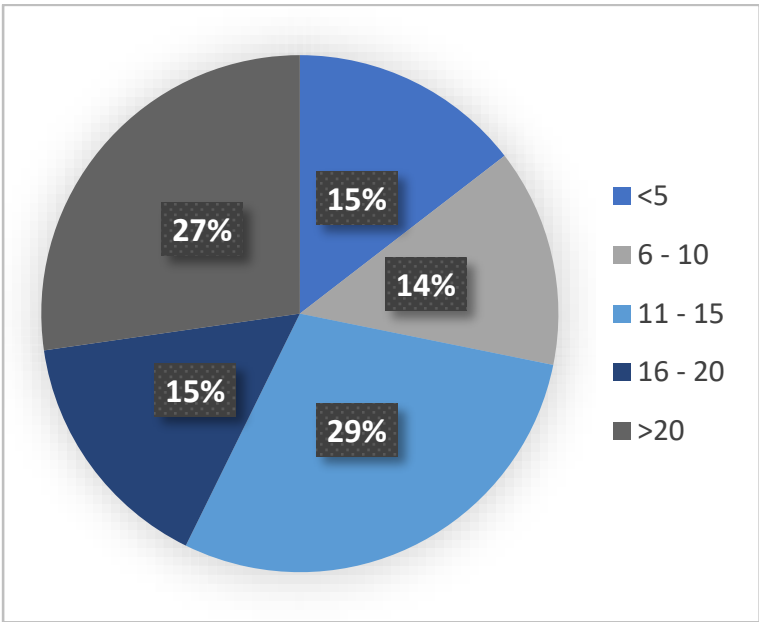

Fig. 2. Working experience

Survey shows that $66 \%$ per cent has some experience in the project environment, while $18 \%$ per cent of respondents are entirely experienced with more than ten projects in their careers. Results are shown in Figure 3.

Participants of the survey were asked to give answers using the Likert Scale. Sixteen questions were asked to get insights on various elements of practice, but also to get an opinion regarding needed competences.

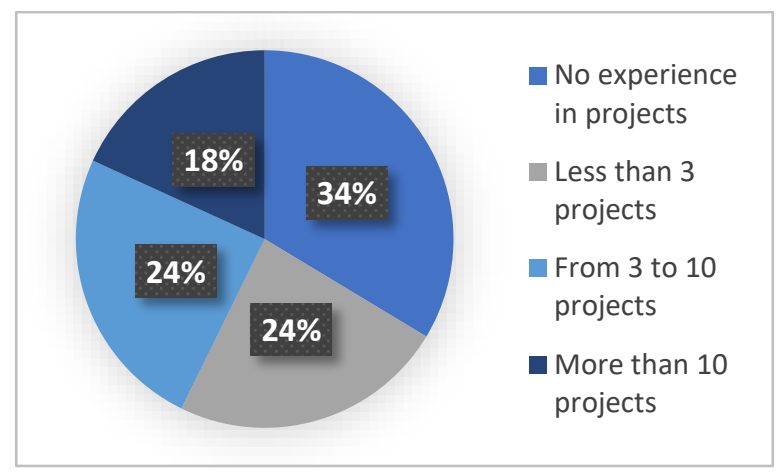

Fig. 3. Experience in projects

In this paper, only the most significant findings would be presented.

When identifying substantial challenges in executing projects, participants state that cooperation on a local and governmental level is quite satisfying with an average score of 2.9 and strategic documents are available with an average of 2,4 which is the best (lowest) score under this question.

When questioning the cooperation on projects, results show that cross-border cooperation and cooperation with economic subjects (companies) are at a low level with an average score of 2.7 and 2.8, respectively.

After the analysis of the present practice in the public project management arena, participants were asked to share their opinion on the ways to improve project management efficiency.

An answer with the highest score is, as expected, professional training and certification in project management with an average rating of 4.50 .

At this point, it is interesting to underline that, according to the opinion of more experienced people (project managers), rank the financial and other bonuses for successful project managers as the most valuable element for enhancing project management with an average score of 4.6 .

At first, this might come as a surprise, but if one takes into account that experienced project managers have probably undergone substantial professional development, further motivation for them be recognised for the success of the project they run.

Having in mind that respondents recognise professional development as the most critical element of the project success, the next question gets to the heart of the essential competences that are needed in contemporary practice.

Results show the following importance of the competences (knowledge and skills) given in table 2 . 
TABLE 2. AN AVERAGE SCORE OF KNOWLEDGE AND SKILLS NEEDED FOR PROJECT MANAGERS

\begin{tabular}{|l|c|}
\hline Competence (knowledge and skills) & Score \\
\hline Project time management & 4.26 \\
\hline Resource and cost management & 4.52 \\
\hline Stakeholder management & 4.30 \\
\hline Risk management & 4.36 \\
\hline Monitoring, control and reporting & 4.44 \\
\hline Analytical skills & 4.51 \\
\hline Communication management & 4.46 \\
\hline Teamwork & 4.61 \\
\hline Delegating & 4.34 \\
\hline Leadership & 4.39 \\
\hline
\end{tabular}

As one can see the most valuable skill is Teamwork with an average score of 4.61 , and most useful (technical) knowledge is on resource and cost management.

Similar results come from more experienced project managers. They also recognise the importance of Resource and cost management with ana average score of 4.76 and Teamwork with a rating of 4.71. The significant distinction from the general sample is in communication management, rated as much as 4.76 by senior project managers. This lead to a conclusion that experience brings communication as a vital skill for project success before all others. Consequently, this is in line with many other research results that emphasise communication as an essential element of successful management in general.

Regarding sex of the participants there was no significant difference. An average score of all of the questions showed the difference in a second decimal place, as a maximum between male and female respondents.

\section{CONCLUSION}

Numerous research brings to connection economic growth and resources available to support that very growth. Professionals, researchers and other relevant sources often focus on "traditional" resources such as land, ore, water, energy etc. These resources are undoubtedly valuable, but if one takes a close attention to the most developed economies of the present, it may be concluded that there is no apparent connection between those resources and economic success, i.e. lot of African countries have for instance substantial reserves of diamonds, but it does not make them star economies. On the other hand, some of the fastestgrowing economies in the world (most of them in Europe) are not based on traditional resources but rather on knowledge, skills and experiences. Hence they are often called economies of knowledge.
When we apply the same logic to project management as one of the most critical disciplines helping economies to grow in a fast-forward mode, competence of project managers' and project team members' competences come to the top of the resources in need.

A lot of authors have already recognised both the need and importance of project management competences, but there is not a unique set of them to utilise on every project in any particular context. Hence, evergoing research is needed to show what are the most necessary knowledge, skills and experience in some area, at one specific moment. The aim of this paper, based on empirical research was to show this very necessity in present Serbian context.

Results show that people in project management (project managers and project team members) of various sex, background, education end experience have some similar views. Most of them find professional development essential for project success. They recognise cost and resource management as most valuable knowledge and ability to work in team and to communicate effectively as most useful skills for efficient project management.

Results of the research and findings presented in the paper could have practical use value for policymakers, education and training providers, and professional association.

Policymakers should define career path in project management building people for technical knowledge towards most needed skills in parallel with their way up-the-ladder. Consequently, as the findings show, bonuses should be introduced to keep experienced people in the public system and reduce the rate of fluctuation.

Education and training providers can use the results to tailor adequate professional development programs that would excellently match the public servants training needs. In that way they would both increase efficiency of their operations and also contribute to more successful project management in the public sector.

At last, but not least, professional associations should focus more on professional certification that was recognised as one of the most critical drivers of project success. Establishing a professional certificate as a must-have in public sector project management would inevitably bring to substantial increase in the quality of project management.

Final remark gathering all the findings presented in this paper would be that by developing project management competences in the public sector would significantly contribute to the efficiency of public project management consequently contributing to the faster development of growing economies all over the world. 


\section{ACKNOWLEDGEMENT}

This paper is a result of the Project No. 179081 funded by Ministry of Education and Science of the Republic of Serbia: "Researching Contemporary Tendencies of Strategic Management Using Specialized Management Disciplines in Function of Competitiveness of Serbian Economy.

\section{REFERENCE}

[1] L. H. Crawford, J. Helm, J. "Government and governance: The value of project management in the public sector". Project Management Journal, 40(1), 2009, pp. 73-87.

[2] D. W. Wirick "Public-sector project management." Meeting the Challenges and Achieving Results, Hoboken/NJ. 2009.

[3] K. M. Rosacker, D. L. Olson "Public sector information system critical success factors." Transforming Government: People, Process and Policy 2(1), 2008, pp. 60-70.

[4] L. Crawford, A. H. Nahmias. "Competencies for managing change." International journal of project management 28(4), 2010, pp. 405-412.

[5] M.. Todorovic, V. Obradovic, V. "Sustainability in project management: a project manager's perspective. U I. Ljumovic, \& A. Elteto (editors), Sustainable Growth and development in small open economies, 2018. pp. 88-107.

6] C. F., Gomes, M. M. Yasin, M. H. Small "Discerning interrelationships among the knowledge, competencies, and roles of project managers in the planning and implementation of public sector projects." International Journal of Public Administration 35(5), 2012, pp. 315-328

[7] V. Obradović, "Contemporary Trends in The Public Sector Project Management. European Project Management Journal, 8(2), 2018, str. 52-56. doi: 10.18485/epmj.2018.8.2.7

[8] L. Geoghegan, V. Dulewicz. "Do project managers' leadership competencies contribute to project success?." Project Management Journal 39(4), 2008, pp. 58-67.
[9] Rwelamila, P. M. (2007). Project management competence in public sector infrastructure organisations. Construction Management and Economics, 25(1), 55-66. Retrieved 5 3, 2019 from http://uir.unisa.ac.za/bitstream/handle/10500/5204/pm competence in public sector.pdf?sequence $=1$

[10] V. Obradovic, P. Jovanovic, N. Djordjevic, I Beric, F. Jovanovic, "Using project management as a way to excellence in healthcare", HealthMED, 21012. pp. 2100-2107.

[11] A. Ammeter, J. Dukerich "Leadership, Team Building, and Team Member Characteristics in High Performance Project Teams", Engineering Management Journal, 14(4), 2002.

[12] S. Gillard, J. Price, "The Competencies of Effective Project Managers: A Conceptual Analysis. The International Journal of Management, 22(1), 2005. 48. Retreived 5 3, 2019 from https:/questia.com/library/journal/1p3-828197891/thecompetencies-of-effective-project-managers-a

[13] R. Boyatzis, R. "The Competent Manager. A Model For Effective Performance". New York: John Wiley \& Sons, 1982.

[14] V. Obradovic, V. "Model upravljanja promenama primenom metodologije projektnog menadzmenta", Srbija: Univerzitet u Beogradu, 2010

[15] B. Lloyd-Walker, D. Walker "Authentic leadership for 21st century project delivery." International Journal of Project Management 29(4), 2011, pp. 383-395.

[16] B. M. Maseko, "Leadership styles deployed by women project managers". Gender and behaviour, 11(2), 2013, pp. 5663-5672. $\begin{array}{lllll}\text { Retrieved } & 5 & 3, & 2019 & \text { from }\end{array}$ https://journals.co.za/content/genbeh/11/2/ejc144837

[17] L. Richman, "Improving Your Project Management Skills (2nd edition) New York: American Management Association, 2013.

[18] K. R.Wills "Essential Project Management Skills" Retrieved 5 3, 2019 from https://taylorfrancis.com/books/9781439827178

[19] D. H. Stevenson J A. Starkweather "PM critical competency index: IT execs prefer soft skills." International Journal of Project Management 28(7), 2010, pp. 663-671. 